\title{
The Effect of Internal Communication on the Performance of Educational Personnel at the Cirebon Maritime Academy
}

\author{
Fereddy Siagian \\ Ceribon Maritime Academy \\ *Corresponding Author: fredysiagian81@ gmail.com |Phone Number: +6281383214444
}

\begin{abstract}
The purpose of this study is to find out and analyze the effect of internal communication on the performance of educational staff. This type of research uses descriptive and quantitative research. The population in this study amounted to 102 people, using the Slovin formula obtained a sample of 51 people with a simple random sampling technique. The testing instrument uses a validity test and a reliability test. While the data analysis technique used is a simple regression analysis with the $t$ test and the coefficient of determination test. From the results of the research data obtained values for internal communication variables of $(9,852)>(2,011)$ with a sig value of $0,000<$ from the value of 0.05 . Meanwhile for the $R$ Square value obtained a result of 0.669 , meaning that the change in the performance of the teaching staff at the Cirebon AMC Educational Institution was $66.9 \%$ influenced by internal communication while the remaining $33.1 \%$ was caused by other variables not examined. The conclusion of this study is that internal communication greatly influences the performance of educational staff in the work environment of the Cirebon AMC Educational Institution. good to better demonstrate the success of the Cirebon Maritime Academic Educational Institute.
\end{abstract}

Keywords: internal communication; performance; educational personnel;

\section{Introduction}

Human resources, one of the most valuable assets owned by an organization or government agency. Human Resources are the only resources that can drive other resources. Thus, the element of human resources is one of the key factors that an organization or government agency must maintain in line with the demands that an organization always faces to answer any existing challenges. Likewise in an educational institution, educational personnel are very important in determining the success of the quality of education of the institution. Human resources in an educational institution have a major role in increasing the effectiveness and efficiency of an educational institution in various learning management activities. In addition, the very high demands of educational institutions demand the resilience of the institution in bridging various problems both internally and externally. Resilience in these educational institutions is largely determined by good communication between institutional leaders and educational personnel. This is because in carrying out all the activities of an educational institution to achieve its mission and goals, it really depends on the way humans communicate with each other who manage the educational institution. In educational institutions the meaning of communication plays a very important role, where in doing work among fellow education personnel requires effective communication so that messages about work can be understood. The effectiveness of communication will run well if both understand the meaning of the communication information. In other words, every individual in educational institutions needs to relate and communicate harmoniously, so that the goals that have been set can be achieved effectively and efficiently through close and harmonious cooperation.

Performance problems are inseparable from processes, results and usability, in this case performance or work performance is the quality and quantity of work achieved by an educational staff in carrying out its duties in accordance with the responsibilities assigned to it. Where according to Syamsir T (2014: 74) defines performance ( performance) is the quantity and quality of the work of individuals or groups within the organization in carrying out main tasks and functions that are guided by norms, standard operating procedures, criteria and measures that have been set or are applicable in organization, while according to Mangkunegara (2013) performance is the quality and quantity of work achieved by an employee in carrying out his duties in accordance with the responsibilities given to him in this case is the educational staff. The 
good performance of the teaching staff will directly affect the performance of the institution, and to improve the performance of the teaching staff is a time-consuming and long process. Apart from increasing supervision and guidance, an assessment is also carried out on the level of work success performed by employees.

Performance appraisal is also useful as a measure that can be used to improve the performance of the education personnel concerned. To be able to improve the performance of education personnel, it is very important for these educational institutions to find out what causes a decrease or increase in the performance of education personnel who work at the Cirebon Maritime Academy (AMC) educational institution. Several factors that can affect the performance of education personnel include internal communication (Sirait, 2014).

At present, in the Cirebon Maritime Academy (AMC) educational institution, it can be said that the performance of educational personnel is still not maximal in regulating the learning process. This is indeed still a lack of internal communication between the education staff themselves. As we all know that communication is very important because it means all activities of human life in everyday life, activities that cannot be separated from human life, namely communication activities. With communication, humans can build relationships between fellow humans. Communication by humans can be done verbally or nonverbally. According to Bernard Berelson and Gary A. Steiner \& Theodore M. Newcomb, the meaning of communication is: Bernard Berelson and Gary A. Steiner (in Mulyana, 2010: 68) state that, "Communication is the transmission of information, ideas, emotions, skills, and so on by using symbols, words, pictures, figures, graphics, and so on. The act or process of transmission is what is usually called communication. "

And as stated by Sabri and Safitri (2016), internal communication is related to the relationship between an organization and employees. The main thing in internal communication is employees at all levels, including management and at all locations. And based on the results of interviews conducted by researchers with education personnel in the AMC office, internal communication that occurs between educational staff who do not talk to each other due to personal problems, education staff also have obstacles because the rooms of each section are separate and far apart from other parts. These problems cause education staff to feel uncomfortable working and feel worried about interfering with the duties of other education personnel at work. In addition to interviews, researchers also make observations on educational staff who only speak as necessary with employees in other fields, educational staff are also reluctant to talk to superiors so that education staff are afraid to express opinions or complaints about the assignment given. With such circumstances it can be said that the working atmosphere in the Cirebon Maritime Academy (AMC) educational institution is still not optimal, especially in matters of internal communication within the scope of work of the Cirebon Maritime Academy (AMC) educational institution.

Based on the description above, it is clear that there are indeed internal communication problems within the Cirebon Maritime Academy Education Institute (AMC) which have not yet been shown to be maximal. Therefore, here the researcher is eager to investigate further how much influence internal communication has on the performance of teaching staff in the Cirebon Maritime Academy Education Institute. S ehingga researchers need to lift a thesis entitled: "The Effect of Internal Communication Performance Against Personnel In the Institutions of the Cirebon Maritime Academy (AMC)".

\section{Materials and Methods}

This type of research uses descriptive and quantitative research. Descriptive statistics are statistics used to analyze data by describing or describing the data that has been collected as it is without intending to make general conclusions or generalizations (Sugiyono, 2016: 238-239). Meanwhile, quantitative methods can be interpreted as data collection using research instruments, data analysis is quantitative/statistical in nature with the aim of testing the predetermined hypothesis. The population used in this study were all educational personnel in the work scope of the Cirebon Maritime Academy education institution, totaling 102 people, using the Slovin formula with a tolerable error rate of $10 \%$, so the number of samples used in this study was 51 educational staff. With the sampling technique used is probability sampling, while the technique of sampling method uses random sampling ( simple random sampling).

In a scientific research, data collection methods are intended to obtain relevant, accurate, reliable materials (Arikunto, 2013 ). The data collection technique used in this research is to use the interview method (interview), the questionnaire method (questionnaire), the method of observation (observation), and the method of documentation. With s when measuring used in this study is the scale Likert, according to (Sugiyono, 2014 ). While t eknik data analysis in this study uses regression statistical analysis that is simple and hypothesis testing (test $t$ ), with $t$ ingkat significance used in this study amounted to 0.05 or $5 \%$. However, before the data analysis technique was carried out, all research instruments were tested for data quality through validity and reliability tests. 


\section{Results and Discussions}

a. Validity and Reliability Test Results

According to Wiratna Sujarweni (2015: 165) the validity test is used to measure whether a questionnaire is valid or not. While the reliability test according to Danang Sunyoto (2015: 143) questionnaire items are said to be reliable if someone's answer to the questionnaire is consistent. D ari instrument data quality test results through the validity and reliability can be seen that all items in the statement of variable internal communication and education personnel performance variables obtained results can be seen in the table below. $\mathrm{D}$ ith sample as many as 51 people so the obtained value $\mathrm{r}_{\text {table }}$ at $\mathbf{0 . 2 3 7}$. And a variable is said to be reliable if it gives a Cronbach Alpha value > 0.60. (Ghozali, 2016).

Table 1. Test of the Validity of Research Variables

\begin{tabular}{|c|c|c|c|}
\hline Variable & Item No & Corrected Item-Total Correlation & Cronbach Alpha \\
\hline \multirow{6}{*}{ Internal Communication $(\mathrm{X})$} & $X-1$ &, 863 & \multirow{6}{*}{0.946} \\
\hline & $X-2$ &, 851 & \\
\hline & $X-3$ & 906 & \\
\hline & $\mathrm{X}-4$ & 869 & \\
\hline & $X-5$ &, 814 & \\
\hline & $\mathrm{X}-6$ &, 712 & \\
\hline \multirow{10}{*}{$\begin{array}{l}\text { Educational Personnel } \\
\text { Performance }(Y)\end{array}$} & Y1 & 826 & \multirow{10}{*}{0.945} \\
\hline & $\mathrm{Y} 2$ &, 837 & \\
\hline & $\mathrm{Y3}$ & 884 & \\
\hline & $\mathrm{Y} 4$ & 602 & \\
\hline & $Y 5$ & 874 & \\
\hline & $\mathrm{Y} 6$ &, 706 & \\
\hline & Y7 & 737 & \\
\hline & $\mathrm{Y} 8$ & 742 & \\
\hline & Y9 &, 800 & \\
\hline & $\mathrm{Y} 10$ &, 828 & \\
\hline
\end{tabular}

From the table above shows that the validity and reliability tests for all research variables obtained the results of all statement items having a value of $r$ count $>$ from the value of $r$ table 0,237 with the cronbach alpha value of each variable with a value of $>0.60$. Thus all statements in the research variables are declared valid and reliable so that they can be continued as data material in this study.

b. Results of Linear Regression Analysis Simple and Hypothesis Testing ( $T$ test)

Regression analysis is a study of the dependence of the dependent variable with one or more independent variables. The purpose of regression analysis, in addition to measuring the strength of the relationship between one or more variables, also shows the direction of the relationship between the dependent variable and the independent variable (Ghozali, 2013).

And the $t$ test shows how far the influence of an explanatory or independent variable individually in explaining the variation of the dependent variable (Ghozali Imam, 2013: 98). And to find out the $t$ table value, it is done by first looking for the degree of freedom/ $\mathrm{df}$ ( degree of freedom ) by using the formula $\mathrm{df}=$ $\mathrm{nk}$, where $\mathrm{n}$ is the sample and $\mathrm{k}$ is the number of independent and dependent variables. The level of significance used in this study is 0.05 or $5 \%$. And the results of the regression test and hypothesis testing can be seen in the table 2 .

Table 2. Analysis of Linear Regression Simple

\begin{tabular}{|c|c|c|c|c|c|}
\hline \multirow{2}{*}{ Model } & \multicolumn{2}{|c|}{ Coefficient } & & \multirow{2}{*}{ Sig. } & \multirow{2}{*}{$\mathrm{R}^{2}$} \\
\hline & Score & Std. Error & & & \\
\hline Constant (a) & 9,717 & 4,269 & \multirow{2}{*}{9,852} & \multirow{2}{*}{, 000} & \multirow{2}{*}{0.669} \\
\hline Internal Communication &, 960 &, 097 & & & \\
\hline
\end{tabular}

Based on the table 2 above can be seen for $\mathrm{n}$ use values constant performance of educators at 9.717 . Performance value without any other influence. For the internal communication regression coefficient value , the value is 0.960 , meaning that internal communication has a positive effect in increasing the performance of education personnel by $1 \%$ or by 0.960 . This shows that with the existence of internal communication that is well established in the work environment of the Cirebon Maritime Academy Education Institute (AMC), it can be ascertained that the performance of educational personnel will also increase. 
In addition to that of table 2 above can be known $\mathrm{h}$ acyl $\mathrm{t}$ test , $\mathrm{t}$-test, which is then compared to the value that is $\alpha=0.05$ and $n=$ number of samples (51), with the formula $\mathrm{df}=\mathrm{nk}$, where $\mathrm{n}$ is the observation while $\mathrm{k}$ is the number of variables (free and bound), then the value is 2.011. From the results of the value of the internal communication variable, it was obtained a value of $9.852 \geq 2.011$ with a significance of $0.000 \leq \mathrm{sig}$ 0.05 , this means that the hypothesis $\mathbf{H a}$ is accepted and Ho is rejected or the Internal Communication hypothesis has a positive and significant effect on the performance of education personnel can be accepted. And of the value of $\mathrm{R} 2$ the result of 0,669 , meaning that the variable communication interna give effect to the performance of educators of 0,669 or in other words the influence of the independent variables on the dependent variable of $66.9 \%$ while the remaining $33.1 \%$ were caused by other variables not included are examined in the research framework.

According Yulius Eka Agung Saputra (2014: 173) internal communication is the exchange of ideas among administrators and educators in an Institute of education, the complete structure of a typical accompanied by an exchange of ideas horizontally and vertically in the organization are, so that jobs can run well . Meanwhile, according to Akhmad Subkhi MM and Mohammad Jauhar, S.Pd. (2013: 274) communication is a basic human activity that is interconnected with each other in everyday life at home, at work, in the market, in society or anywhere humans are.

Likewise in the scope of the AMC Educational Institute in Cirebon City, communication is very important, especially internal communication, because the success of an educational institution is one of which is the existence of good communication among its employees, namely educational staff. This is also in accordance with the research of Andri Setiadi (2013) which shows that the internal communication variable has a positive and partially significant effect on employee performance at UD. Rezeki Surabaya.

\section{Conclusions}

The conclusion obtained from the results of this study is that internal communication has a positive and significant effect on the performance of teaching staff at the Cirebon Maritime Academy Education Institute (AMC) of $66.9 \%$ with a value of $9.852 \geq 2.011$ with a significance of $0.000 \leq$ sig 0.05 . Thus, internal communication has a very positive influence in improving the performance of educational personnel at the Cirebon Maritime Academy Education Institute (AMC). By Komu nikasi internal that exists both this raises the good performance of education personnel in implementing all the work programs in the Institutions of the Maritime Academy of Cirebon (AMC).

\section{Acknowledgement}

The authors would like to thanks the supervisors from Ceribon Maritime Academy for their assistance in the completed this study.

\section{Author's Contributions}

Author discussed the results and contributed to from the start to final manuscript.

\section{Conflict of Interest}

The authors' declare that they have no competing interests.

\section{References}

Arikunto, Suharsimi. (2013). Research Procedure A Practical Approach. Jakarta: Rieneka Cipta

Ghozali, I. (2013). Multivariate Analysis Application with IBM SPSS 21 Update PLS Regression. Semarang: Diponegoro University Publishing Agency.

Ghozali, I. (2016). Multivariate Analysis Application with the IBM SPSS 23 Edition 8. Undip Publisher Agency: Semarang.

Mangkunegara, AAAP (2013). Human Resource Management, (Revised Edition). BandunG: Publisher PT.Remaja Rosda Karya.

M. Shabri, Amri, \& Safitri, Husnaina Mailisa. (2012). The Influence of Leadership Style, Teamwork, and Communication Style on Job Satisfaction and its Impact on Employee Performance at the Regional Secretariat of Sabang City. Management Journal , Vol 2, No 1. (www.rp2uprodipps.unsyiah.ac.id/Jurnalmm/index, accessed November 11, 2016). 
Mulyana, Deddy. (2010). An Introduction to Communication Studies. 14th Printing. Bandung: PT Remaja Rosdakarya.

Saputra, Yulius Eka Agung. (2014). Management and Organizational Behavior. Yogyakarta: Graha Science.

Sirait, R. (2014). The Influence of Supervision and Work Environment on the Work Effectiveness of Teachers at the Business Management Vocational School of the Trisakti Lubuk Pakam Education Foundation. [essay]. Medan (ID): USU's Faculty of Economics and Business

Subkhi, A. \& Jauhar, M. (2013). Introduction to Organizational Theory and Behavior . Jakarta: Literature Achievement.

Sujarweni, Wiratna. (2015). Yogyakarta Business and Economic Research Methodology: PT.Pustaka Baru Sugiyono. (2014). Qualitative and Quantitative Research Methods R \& D. Bandung: CV Alfabeta

Sugiyono. (2016). Management Research Methods. Bandung: Alfabeta Publisher

Sunyoto, Danang. (2015). Human Resources Research. Yogyakarta. CAPS

Sunyoto, Danang. 2015. Accounting Research Methodology. Bandung: Refika Aditama.

Torang, Syamsir. (2014). Organization and Management. Bandung: Alfabeta Publisher 